\title{
IMPACT OF SOCIAL CAPITAL ON HEALTH SAFETY DURING THE SARS - COV - 2 FLU PANDEMIC
}

doi:10.2478/czoto-2021-0032

Date of submission of the article to the Editor: $30 / 11 / 2020$

Date of acceptance of the article by the Editor: $24 / 03 / 2021$

Felicjan Bylok ${ }^{1}$-orcid id: 0000-0001-5305-86340000

${ }^{1}$ Czestochowa University of Technology, Poland

\begin{abstract}
This paper describes the role of social capital in terms of stimulating activities aimed at improving health safety in times of the Covid 19 pandemic. Ensuring health safety constitutes one of the fundamental aims of every health care system, which is executed by means of multiple institutions associated with health care, as well as through collective action. Social capital stimulates collective action with the aim of stopping the spread of the pandemic. The aim of this paper is to search for ties between social capital and the spread of the pandemic in Poland. As a result of empirical research, it was established that strong social capital had a significant impact on the lower number of Covid-19 infections in provinces in Poland. Simultaneously, this impact is dependent on the level of infections in society. The greater the number of Covid-19 infections, the less social capital restricts the spread of the pandemic.
\end{abstract}

Keywords:Social capital, social networks, trust, health safety, Covid-19

\section{INTRODUCTION}

In December 2019 in Wuhan, China, a new coronavirus emerged (SARS-CoV-2), which evoked an epidemic of acute respiratory syndrome (COVID-19). A pandemic was declared, which became a threat to the health safety of all the countries of the world. It significantly reduces the level of health safety of individuals and social groups and this state of affairs has a negative impact on other subjective areas of safety, such as the following: economic security, political security, public safety, military security and security of information. The task for state authorities and institutions of health care is to create and guarantee protection for their citizens against the threats to their health, regardless of their age, sex type, place of abode, income and wealth. During the pandemic, the radical reduction of the availability of the health care system has been observed, which in turn reduces the level of health safety. In almost all of the countries affected by the pandemic, the health care system is overloaded. The activities undertaken by entities that deal with the fight against the pandemic require the acceptance of society. A significant role in terms of strengthening this level of acceptance may be played by social capital.

The aim of this paper is to search for ties between social capital and the spread of the pandemic in Poland. The author at hand searches for answers to the following 
research questions: What is the scope of occurrence of social capital in Poland? To what extent do the elements of social capital, namely, social networks, trust and civic activity support activities aimed at mitigating the spread of the pandemic? The method of desk research and the deductive methods were availed in the research.

\section{SOCIAL CAPITAL AND THE SARS - COV - 2 FLU PANDEMIC}

The concept of social capital became attractive for researchers in search of clarification of the processes in the area of public health. In particular, in this period of decreased health safety evoked by the pandemic, social capital may play a significant role in terms of mitigating the spread of the pandemic.

The approaches to social capital are varied at the level of conceptualization and operationalization. It is possible to distinguish five fundamental ways of its perception. Firstly, as a social network, namely, the structure of ties between two or more participants (Coleman, 1988). Secondly, as the theory of criteria, which opines that social capital refers to integrity, criteria and values embedded in a social network (Fukuyama, 1997). Thirdly, as the theory of resources, according to which social capital is a set of actual and potential resources which are associated with having a long-lasting network that involves more or less institutionalized ties based on mutual familiarity and acknowledgement (Bourdieu, 1986). Fourthly, as the theory of abilities, in which social capital relates to the relationship between entity and society, while also the ability to adopt limited resources from such a connection (Portes, 1998). Fifthly, as the theory of the features of collectivity that include networks, norms, trust, social activity facilitating the coordination and cooperation aimed at mutual benefits (Putman, 1994). For the purposes of this paper, the author at hand accepts that social capital shall signify the component of the skills of cooperation and coworking of individuals with the framework of communities for the execution of joint goals.

Analysis of these notions facilitates the distinction of the most frequently enumerated composite elements of capital, which first and foremost include participation in social networks, civic engagement (voluntary work) and trust in people and institutions. A particularly important role is attributed to social networks. Generally speaking, an individual must invest in building social networks in order to achieve the specified tangible and intangible benefits.

During the pandemic, the application of the appropriate pro-health behavioural patterns reduces the pace of the spread of the virus. Social capital may play a significant role in this process. Its structural element, namely, social networks, may prevent the spread of this virus. An important task lies with the central figure of this network, who is the link with the other members of the network. Propagating positive behavioural patterns associated with safety, e.g. washing hands, maintaining social distance, wearing masks and receiving vaccines on the part of the central figures may slow down the spread of the spread of the pandemic. The acquisition of central figures, e.g. leaders in local communities, with the aim of building the levels of involvement and trust in the institutions of health care may increase the efficiency of activities in the area of public health (Bavel et al., 2020).

Likewise, as a relational element, trust is of significant importance in the fight against the pandemic, particularly institutional trust in the government and the institutions of public health. During this pandemic, the representatives of state authorities and health care have the task to convince people to adhere to the medical recommendations, namely, refrain from social contacts, conform with quarantine regulations, or have 
tests carried out. The efficiency of these actions to a large extent depends on trust. The research of Freimuth et al. (2014) on the impact of trust on the course of the $\mathrm{H} 1 \mathrm{~N} 1$ epidemic in the USA in 2009 indicates the important role of trust as a predictor of social behaviour. The researchers discovered that the representatives of the government and the medical institutions are bestowed with trust when public opinion deems them to be competent experts in the sphere of health. The significance of institutional trust in terms of counteracting the pandemic was indicated by van der Weerd et al. (2011), who observed the impact of trust in terms of human behaviour during the course of the $A(\mathrm{H} 1 \mathrm{~N} 1)$ pandemic in the Netherlands. The conclusion arising from the research is the emphasis on the significance of trust in the government as the important intermediary between an individual and infection.

One of the effective methods of counteracting the spread of the pandemic is the application of vaccines. Research conducted by B. Rönnerstranda (2013) indicates that social capital may become an intermediary between an individual and vaccination. There is a relation between the indicators of social capital and the readiness to receive vaccination against contagious diseases. A high level of institutional trust, as well as the general sense of trust have a positive impact on the intention to receive vaccination. Gilles et al. (2011) suggest that public trust is a key determinant in the behavioural patterns associated with vaccination. Its reduction causes negative consequences for the acceptance of vaccines. The increase in the level of trust is also evoked by "credible sources", which are well-known people. For instance, the disclosure of information by former president Barack Obama relating to the vaccination of his daughters had a great influence on decisions relating to vaccination among people, regardless of their political affiliations, or even trust in government activities, particularly the president himself (Quinn et al., 2013).

\section{SOCIAL CAPITAL AND COVID 19 PANDEMIC. CASE OF POLAND}

Research on the relation between social capital and its elements and infections SARS-CoV-2 infections was conducted on the basis of data relating to the number of infections per 10,000 inhabitants in provinces and the indicators of social capital, which includes activity in social organizations, social trust and participation in social networks. Provinces were availed of as units for analysis. Analysis of the data presented in Table 1 reveals that the level of social capital in Poland is at a relatively low level (21.45). The highest level of social capital occurs in the province of zachodnio-pomorskim, followed by the provinces of mazowieckie, kujawskopomorskie, warmińsko-mazurskie and mazowieckie. However, the lowest level was noted in the provinces of tódzkie and opolskie. The difference between the highest and the lowest level of social capital amounts to 18.97, which indicates the significant disproportion between the provinces.

A detailed analysis of the indicators of social capital facilitates the identification of significant differences between them in the analysed regions. The lowest level related to the indicator of participation in social networks amounting to 10 or more members (31.88). Simultaneously, the most people who participated in these networks were in the northern provinces, namely, zachodniopomorskie, warmińsko-mazurskie and pomorskie. The indicator of social trust achieved a lower level (19.45), whereas the highest level was noted in the provinces of mazowieckie, kujawsko-pomorskie and pomorskie. In turn, the indicator of social activity (14.04) was the highest in the provinces of zachodnio-pomorskie, podlaskie and małopolskie. 
Table 1

Indicators of social capital In provinces in percentage form

\begin{tabular}{|c|c|c|c|c|}
\hline \multirow[t]{2}{*}{ Province } & $\begin{array}{l}\text { Social } \\
\text { trust }\end{array}$ & $\begin{array}{l}\text { Social } \\
\text { activity }\end{array}$ & $\begin{array}{l}\text { Membership of } \\
\text { social networks of } \\
10 \text { or more people }\end{array}$ & $\begin{array}{l}\text { Generalised } \\
\text { social capital } \\
\text { indicator }\end{array}$ \\
\hline & ST & SA & SN & SC \\
\hline Dolnośląskie & 16.56 & 14.82 & 24.69 & 18.69 \\
\hline Kujawsko-pomorskie & 27.55 & 9.82 & 35.44 & 24.27 \\
\hline Lubelskie & 14.75 & 12.64 & 28.10 & 18.49 \\
\hline Lubuskie & 11.67 & 14.64 & 28.33 & 18.21 \\
\hline Łódzkie & 6.80 & 4.10 & 27.89 & 12.93 \\
\hline Małopolskie & 21.98 & 18.57 & 24.31 & 21.62 \\
\hline Mazowieckie & 29.87 & 13.54 & 36.91 & 26.77 \\
\hline Opolskie & 17.65 & 6.00 & 26.92 & 16.85 \\
\hline Podkarpackie & 12.87 & 17.82 & 31.38 & 20.69 \\
\hline Podlaskie & 17.11 & 18.71 & 23.68 & 19.83 \\
\hline Pomorskie & 26.13 & 8.14 & 35.13 & 23.13 \\
\hline Śląskie & 13.30 & 17.12 & 30.74 & 20.39 \\
\hline Świętokrzyskie & 23.89 & 11.70 & 31.82 & 22.47 \\
\hline Warmińsko-mazurskie & 22.99 & 16.04 & 41.63 & 27.00 \\
\hline Wielkopolskie & 23.89 & 18.03 & 33.93 & 25.28 \\
\hline Zachodnio-pomorskie & 24.18 & 22.97 & 45.50 & 31.90 \\
\hline
\end{tabular}

Source: Prepared on the basis of (Czapiński, Jerzyński, 2016).

One of the aims of the research was the definition of the relations between social capital and the level ofSars - CoV - 2 infections. The relations between these variables are illustrated in Table 2. Depending on the period in which research was conducted on the impact of social capital on the number of infections per 10,000 inhabitants was varied. In the first period of analysis from 25 March to 27 July 37,521 infections were noted. Significant relations between social capital and the number of infections were observed. In the majority of the provinces, the magnitude of social capital had an influence on the level of infections. A significant positive impact was noted in, among other areas, the provinces of zachodniopomorskie $(\mathrm{SC}=31.9$, IR1=3,74), warmińsko-mazurskie $(S .=27.0, \quad I R 1=1,98)$, kujawsko-pomorskie $(\mathrm{SC}=24,27, \mathrm{IR} 1=3.35)$ and podkarpackie $(\mathrm{SC}=20.69$, $\mathrm{IR} 1=3.01)$. In these regions, a relatively high level of social capital and low level of infections occurred. Nevertheless, a negative relation was observed in the case of the province of łódzkie, in which a low level of social capital and a high level of infections occurred.

Together with the growth of the number of Covid-19 infections, the relations between the variables changed. In the subsequent period from 25 March to 20 October in Poland, 82,862 cases of infections were noted. In relations between social capital and the number of infections, only slight changes were noted. First and foremost, in the provinces of zachodniopomorskie $(\mathrm{SC}=31.9$, IR2 $=29.31$ ), warmińsko-mazurskie $(\mathrm{SC}=27.0, \mathrm{IR} 2=28,65)$ and kujawsko-pomorskie $(\mathrm{SC}=24.27, \mathrm{IR} 2=42.49)$ a relatively high level of social capital had an impact on the level of infections. Secondly, it was observed that the relatively low level of social capital also had an impact on the lower level of infections in the case of the provinces of lubuskie $(S C=18.21, I R 2=28.76)$, dolnośląskie $(S C=18.69$, IR2=35.72) and lubelskie $(S C=18.49, I R 2=36.10)$. Thirdly, 
the low level of social capital still had an impact on the high number of infections in the provinces of łódzkie ( $S C=6.9, \mathrm{IR} 2=58.27$ ) and opolskie $(\mathrm{SC}=16.85, \mathrm{IR} 2=56.34)$.

In the subsequent period under analysis from 25 March to 21 January 2021, a very high number of infections totalling 1,457,755 cases was noted. Significant changes in the relations between social capital and the number of infections took place in the particular provinces. The strongest positive impact of social capital on the number of infections was observed in the provinces of mazowieckie $(S C=26.77, I R 3=327.8)$, świętokrzyskie ( $S C=22.47$, IR3=305.15), podkarpackie $(S C=20.69$, IR3=303.10) and lubuskie $(\mathrm{SC}=18.21, \mathrm{IR} 3=168.48)$. In the case of some provinces the situation took place whereby a high level of social capital was noted together with a high level of infections. This related to the provinces ofzachodniopomorskie $(S C=31.9$, IR3=443.71), warmińsko-mazurskie $(S C=27.0, \quad I R 3=449)$, kujawsko-pomorskie $(\mathrm{SC}=24.27, \mathrm{IR} 3=443)$ and wielkopolskie $(\mathrm{SC}=25.28, \mathrm{IR} 3=423.85)$ and pomorskie $(\mathrm{SC}=23.13, \mathrm{IR} 3=414.72)$.

Table 2.

Indicators of social capital and indicators of illnesses in a time perspective in provinces in Poland

\begin{tabular}{|l|l|l|l|l|}
\hline Province & $\begin{array}{l}\text { Generalised } \\
\text { social capital } \\
\text { indicator }\end{array}$ & $\begin{array}{l}\text { Incidence rate } \\
24.07 .2020\end{array}$ & $\begin{array}{l}\text { Incidence rate } \\
20.10 .2020\end{array}$ & $\begin{array}{l}\text { Incidence rate } \\
21.01 .2021\end{array}$ \\
\cline { 2 - 5 } & SC & IR1 & IR2 & IR3 \\
\hline Dolnośląskie & 18,69 & 10.24 & 35.78 & 333.34 \\
\hline Kujawsko-pomorskie & 24.27 & 3.35 & 42.69 & 483.00 \\
\hline Lubelskie & 18.49 & 3.67 & 36.10 & 345.42 \\
\hline Lubuskie & 18.21 & 0.88 & 28.76 & 168.48 \\
\hline Łódzkie & 12.93 & 36.05 & 58.27 & 385.79 \\
\hline Małopolskie & 21.62 & 5.90 & 104.67 & 337.34 \\
\hline Mazowieckie & 26.77 & 9.90 & 49.04 & 327.80 \\
\hline Opolskie & 16.85 & 10.2 & 56.34 & 405.60 \\
\hline Podkarpackie & 20.69 & 3.99 & 50.65 & 303.10 \\
\hline Podlaskie & 19.83 & 7.62 & 40.20 & 329.25 \\
\hline Pomorskie & 23.13 & 3.01 & 50.00 & 414.72 \\
\hline Śląskie & 20.39 & 30.43 & 69.98 & 371.96 \\
\hline Świętokrzyskie & 22.47 & 6.92 & 46.41 & 305.15 \\
\hline $\begin{array}{l}\text { Warmińsko- } \\
\text { mazurskie }\end{array}$ & 27.00 & 1.98 & 28.65 & 449.00 \\
\hline Wielkopolskie & 25.28 & 8.96 & 48.22 & 423.85 \\
\hline $\begin{array}{l}\text { Zachodnio- } \\
\text { pomorskie }\end{array}$ & 31.9 & 3.74 & 29.31 & 443.71 \\
\hline
\end{tabular}

Source: (SerwisRzeczypospolitejPolskiej2020)

Notes: IR - incidence per 10,000 province residents

The analysis of the impact of the particular elements of social capital on the number of Covid-19 infections per 10,000 inhabitants is significant for the aims of this paper. In analysing the participation in social networks, it was observed that in provinces of a relatively high level of affiliation to social networks a low level of infections was evident. This refers to the provinces of mazowieckie $(\mathrm{SN}=36.91, \mathrm{IR}=327.8, \mathrm{MR}=7.49)$, podkarpackie $\quad(\mathrm{SN}=31.38, \quad \mathrm{IR}=303.1, \quad \mathrm{MR}=9.75)$, świętokrzyskie $\quad(\mathrm{SN}=31.82$, $I R=305.15, \quad M R=8.48) \quad$ and lubuskie $\quad(S N=28.33, \quad I R=168.48, \quad M R=4.16)$. 
Simultaneously, there was also a situation in which provinces of a high level of social capital also witnessed a high rate of infections. This related to provinces of zachodniopomorskie $\quad(\mathrm{SN}=45.5, \quad \mathrm{IS}=443.71, \quad \mathrm{MR}=8.22), \quad$ warmińsko-mazurskie $(\mathrm{SN}=41.63, \mathrm{IS}=449$. $\mathrm{MR}=10.66)$, wielkopolskie $(\mathrm{SN}=33.93, \mathrm{IS}=423.85, \mathrm{MR}=10.36)$ and kujawsko-pomorskie ( $\mathrm{SN}=35,44, \mathrm{IR}=483, \mathrm{MR}=9,96)$.

In the analysis of relations between social capital and the level of infections, it was discovered that trust exerts a positive impact on the level of infections. The lowest level of infections occurred in provinces of the highest level of trust, namely, in the province of mazowieckie $(T=29.87, I S=327.8, M R=7.49)$, świętokrzyskie $(T=23.89$, $\mathrm{IS}=305.15, \mathrm{MR}=8.48)$ and małopolskie $(\mathrm{T}=21.98, \mathrm{IS}=337.34, \mathrm{MR}=8.56)$. However, in the case of the provinces of kujawsko-pomorskie ( $T=27.55, I S=483.00, M R=9.96$ ), pomorskie $(\mathrm{T}=26.13, \mathrm{IS}=414.72, \mathrm{MR}=8.46)$, and zachodniopomorskie $(\mathrm{T}=24.18$, IS=443.71, MR=8.22), in which a high level of trust was noted, such a dependency failed to occur.

A positive relation between the indicators of social activity and the indicators of infections was observed in the case of the provinces of małopolskie ( $S A=18.57$, $\mathrm{IS}=337.34, \quad \mathrm{MR}=8.56)$, podlaskie $(\mathrm{SA}=18.71, \quad \mathrm{IS}=329.25, \quad \mathrm{MR}=8.39, \quad)$ and podkarpackie $(S A=17.82, I S=337.34, M R=9.75)$. However, in the provinces of zachodniopomorskie $(S A=22.97, I S=443.71, M R=8.22)$ and wielkopolskie $(S A=18.03$, IS=423.85, $M R=10.36$ ) a high level of infections took place in the situation of a relatively high level of social activity.

Table 3

Indicators of social capital and indicators of illnesses and deaths in provinces in Poland in period from 25 March 2020 to 21 January 2021.

\begin{tabular}{|l|l|l|l|l|l|}
\hline Province & $\begin{array}{l}\text { Social } \\
\text { trust }\end{array}$ & $\begin{array}{l}\text { Social } \\
\text { activity }\end{array}$ & $\begin{array}{l}\text { Membership of } \\
\text { social } \\
\text { networks of 10 } \\
\text { or more people }\end{array}$ & $\begin{array}{l}\text { Incidence } \\
\text { rate }\end{array}$ & $\begin{array}{l}\text { Mortality } \\
\text { rate }\end{array}$ \\
\cline { 2 - 6 } & ST & SA & SN & IR & MR \\
\hline Dolnośląskie & 16.56 & 14.82 & 24.69 & 333.34 & 7.78 \\
\hline Kujawsko-pomorskie & 27.55 & 9.82 & 35.44 & 483.00 & 9.96 \\
\hline Lubelskie & 14.75 & 12.64 & 28.10 & 345.42 & 10.74 \\
\hline Lubuskie & 11.67 & 14,64 & 28.33 & 168.48 & 4.16 \\
\hline Łódzkie & 6.8 & 4.10 & 27.89 & 385.79 & 10.04 \\
\hline Małopolskie & 21.98 & 18.57 & 24.31 & 337.34 & 8.56 \\
\hline Mazowieckie & 29.87 & 13.54 & 36.91 & 327.80 & 7.49 \\
\hline Opolskie & 17.65 & 6.00 & 26.92 & 405.60 & 11.72 \\
\hline Podkarpackie & 12.87 & 17.82 & 31.38 & 303.10 & 9.75 \\
\hline Podlaskie & 17.11 & 18.71 & 23.68 & 329.25 & 8.39 \\
\hline Pomorskie & 26.13 & 8.14 & 35.13 & 414.72 & 8.46 \\
\hline Śląskie & 13.3 & 17.12 & 30.74 & 371.96 & 8.62 \\
\hline Świętokrzyskie & 23.89 & 11.70 & 31.82 & 305.15 & 8.48 \\
\hline Warmińsko-mazurskie & 22.99 & 16.04 & 41.63 & 449.00 & 10.66 \\
\hline Wielkopolskie & 23.89 & 18.03 & 33.93 & 423.85 & 10.36 \\
\hline Zachodnio-pomorskie & 24.18 & 22.97 & 45.5 & 443.71 & 8.22 \\
\hline Source: Prepared & &
\end{tabular}

Source: Prepared on the basis of (SerwisRzeczypospolitejPolskiej 2020)

Notes: IR - incidence per 10,000 province residents, MR - deaths due to COVID-19 per 10,000 province residents 


\section{CONCLUSIONS}

The findings of the spatial research on the relations between the elements of social capital and the level of COVID -19 infections in Poland indicate that social capital has an impact on the scope of the spread of COVID-19, while simultaneously it is of significance in terms of the number of infections. With the aim of discovering the dependencies between the variables of social capital and the number of infections, three periods of time were subject to analysis, namely, July and October of 2020, as well as January 2021. The choice of these periods was associated with the course of the pandemic in Poland. The first wave of infections took place in July, whereas the second wave in October, while the beginning of the third wave occurred in January. In the analysed periods, significant changes were noted in terms of the relations between the variables. In the first period and the second period, a positive impact of social capital was noted in terms of the number of infections, whereas in the third period significant changes were observed, whereby the large number of infections weakened the impact of social capital. Hence, the impact of social capital on the number of infections is dependent on the level of infections in society. The greater the number of infections, the weaker the impact of social capital is in terms of spread of the virus.

In the research, it was illustrated that the strongest impact on the level of infections was exerted by structural capital. It was established that participation in social networks of over 10 people mitigates the spread of the virus as the members of the network may acquire more information about the pandemic and behavioural patterns of defence, while also count on support in the case of infection, e.g. the delivery of food supplies, medicine and other items that are essential for life. Likewise, it was indicated that the provinces of the highest level of affiliation to social networks had a low level of Covid-19 infections. A relatively low level of impact on the spread of the pandemic was exerted by relational capital, whose significant element is that of trust. In parts of the provinces with the highest level of trust, a low level of infections was observed. Nevertheless, in the case of several provinces that had the highest number of infections, such a dependency failed to occur. This gives rise to the conclusion that social trust did not have an unequivocal impact on the flattening out of the spread of the pandemic.

In sum, with the aim of enhancing health safety, the activities of local authorities and institutions are essential in that they are aimed at building social capital that in all forms enhances the efficiency of social distancing and other behavioural patterns of defence.

\section{REFERENCES}

Bavel, J.J.V., Baicker, K., Boggio, Capraro, V., Cichocka, A., Cikara, M., Crockett, M.J., Crum, A.J., Douglas, K.M., Druckman, J.N., Drury, J., Dube, O., Ellemers, N., Finkel, E.J., Fowler, J.H., Gelfand, M., Han, S., Haslam, S.A., Jetten, J.Willer, R., 2020. Using social and behavioural science to support COVID-19 pandemic response, Nature Human Behavior, 4, 460-471, DOI: 10.1038/s41562-020-0884-z

Bourdieu, P., 1986. The form of capital, In: Richardson J. (ed.) Handbook of theory and research for the sociology of education, 241-258, Greenwood Press, Westport.

Coleman, J S.,1988. Social Capital in the Creation of Human Capital, American Journal of Sociology, 94 (1), 95-120. 
Czapiński, J., Jerzyński, T., 2016. Międzynarodowy Program Sondaży Społecznych ISSP 2015: Raport [International Social Survey Programme 2015: Report], Instytut Studiów Społecznych im. Profesora Roberta B. Zajonca, Uniwersytet Warszawski.

Freimuth, V. S., Musa, D., Hilyard, K., Quinn, S. C., Kim, K., 2014. Trust During the Early Stages of the 2009 H1N1 Pandemic, Journal of Health Communication,19 (3), pp. 321-339, DOI:10.1080/10810730.2013.811323

Fukuyama, F., 1995. Trust: The Social Virtues and the Creation of Prosperity, Free Press, New York.

Gilles, I., Bangerter, A., Clémence, E.G., Green, T., Krings, F., Staerklé, Ch., WagnerEgger P., 2011. Trust in medical organizations predicts pandemic (H1N1) 2009 vaccination behavior and perceived efficacy of protection measures in the Swiss public, European Journal of Epidemiology, 26 (3), 203-210, DOI: 10.1007/s10654011-9577-2

Portes, A. P. 1998. Social Capital: Its Origins and Applications in Modern Society, Annual Review of Sociology, 24,1-24. DOI: 10.1146/annurev.soc.24.1.1

Putman, R.D., 1994. Making Democracy Work: Civic Traditions in Modern Italy, Princeton University Press, Princeton. New Jersey.

Quinn, S. C., Parmer, J., Freimuth, V. S., Hilyard, K. M., Musa, D., Kim, K. H., 2013. Exploring Communication, Trust in Government, and Vaccination Intention Later in the 2009 H1N1 Pandemic: Results of a National Survey, Biosecur Bioterror, 11 (2), 96-106, DOI:10.1089/bsp.2012.0048

Rönnerstrand, B., 2013. Social capital and immunisation against the $2009 A(H 1 N 1)$ pandemic in Sweden, Scandinavian Journal of Public Health, 41 (8), 853-9, DOI: $10.1177 / 1403494813494975$

Serwis Rzeczypospolitej Polskiej (2020). Mapa zarażeń koronawirusemSARS-CoV-2 w Polsce [Coronavirusinfection map SARS-CoV-2 in Poland]. https://www.gov.pl/web/koronawirus/wykaz-zarazen-koronawirusem-sars-cov-2

van der Weerd, W., Timmermans, D.R., Beaujean, D.J. 2011. Monitoring the level of government trust, risk perception and intention of the general public to adopt protective measures during the influenza $A$ (H1N1) pandemic in the Netherlands, BMC Public Health, 11, 575, DOI:10.1186/1471-2458-11-575 